\author{
๑A. В. Бойчук, В. С. Шадріна, Т. В. Верещагіна \\ ДВНЗ «Тернопільсъкий державний медичний університет \\ ілені І. Я. Горбачевсъкого МОЗ України»

\section{ГІПЕРПЛАЗІЯ ЕНДОМЕТРІЯ - СУЧАСНИЙ СИСТЕМНО-ПАТОГЕНЕТИЧНИЙ ПОГЛЯД НА ПРОБЛЕМУ (ОГЛЯД ЛІТЕРАТУРИ)}

\begin{abstract}
Збереження здоров'я жінок і вивчення захворювань, пов'язаних із гендерною проблематикою, залишаються пріоритетними в медицині. Стаття присвячена актуальній проблемі сьогодення - гіперпластичним процесам ендометрія. У проблемі вирішення даної патології за останні роки накопичилося досить багато інформації щодо етіології, причин виникнення, діагностики та лікування. Мета нашого пошуку - огляд літератури, присвяченої фракторам розвитку, етіології та патогенезу, які відіграють найважливішу роль у розвитку гіперпластичних процесів ендометрія. Ендометрій являє собою гормоночутливу тканину, яка має здатність не тільки до циклічного оновлення майже всього клітинного складу, а й до певного реагування на всі зміни гормонів, цитокінів, молекул адгезії, фракторів росту, біогенних амінів та інших біологічно активних речовин на рівні цілого організму. У статті розглянуто основні ланки етіопатогенезу даної патології, такі, як: естрогенна стимуляція, що поєднується з недостатністю прогестерону, гормон-незалежна пролісерація, запалення, знижений апоптоз, патологічний неоангіогенез, а також порушення імунного статусу в ендометрії. Крім того, коротко подана інформація про нові ключові елементи фракторів розвитку, що сприяє значному покращенню вирішення проблеми у виборі патогенетично обґрунтованих методів діагностики та лікування. У статті показано, що нормальний процес росту клітин вимагає тонкого балансу між гормонами, фракторами росту та молекулами адгезії, у тому числі інтегринами й апоптоз-зв'язаними генами. Переглянуто літературні джерела, в яких відзначається велике число випадків рецидивування гіперплазії ендометрія, що зумовлює посилення контролю у напрямку онконастороженості. Представлена нова класифікація гіперплазії ендометрія (WH094), запропонована Всесвітньою організацією охорони здоров'я, що значно спростить термінологію і розуміння проблеми для клініциста.
\end{abstract}

Ключові слова: гіперплазія ендометрія; онкологічний ризик; апоптоз; стероїдні гормони.

ГИПЕРПЛАЗИЯ ЭНДОМЕТРИЯ - СОВРЕМЕННЫЙ СИСТЕМНО-ПАТОГЕНЕТИЧЕСКИЙ ВЗГЛЯД НА ПРОБЛЕМУ (ОБЗОР ЛИТЕРАТУРЫ)

Сохранение здоровья женщин и изучение заболеваний, связанных с гендерной проблематикой, остаются приоритетными в медицине. Статья посвящена актуальной проблеме современности - гиперпластическим процессам эндометрия. В проблеме решения данной патологии за последние годы накопилось достаточно много информации по этиологии, причинам возникновения, диагностике и лечению. Цель нашего поиска - обзор литературы, посвященной фракторам развития, этиологии и патогенезу, которые играют важнейшую роль в развитии гиперпластических процессов эндометрия. Эндометрий представляет собой гормоночувствительную ткань, которая обладает способностью не только к циклическому обновлению почти всего клеточного состава, но и к определенному реагированию на все изменения гормонов, цитокинов, молекул адгезии, фракторов роста, биогенных аминов и других биологически активных веществ на уровне целого организма. В статье рассмотрены основные звенья етиопатогенеза данной патологии, а именно: эстрогенная стимуляция, сочетающаяся с недостаточностью прогестерона, гормон-независимая пролиферация, воспаление, пониженный апоптоз, патологический неоангиогенез, а также нарушения иммунного статуса в эндометрии. Кроме того, кратко представленная инсормация о новых ключевых элементах фракторов развития способствует значительному улучшению решения проблемы в выборе патогенетически обоснованных методов диагностики и лечения. В статье показано, что нормальный процесс роста клеток требует тонкого баланса между гормонами, фракторами роста и молекулами адгезии, в том числе интегринами и апоптозсвязанными генами. Просмотрено литературные источники, в которых отмечается большое число случаев рецидивирования гиперплазии эндометрия, что приводит к усилению контроля в направлении онконастороженности. Представлена новая классификация гиперплазии эндометрия (WH094), предложенная Всемирной организацией здравоохранения, что значительно упростит терминологию и понимание проблемы для клинициста.

Ключевые слова: гиперплазия эндометрия; онкологический риск; апоптоз; стероидные гормоны.

HYPERPLASIA OF ENDOMETRIUM - A MODERN SYSTEM-PATHOGENETIC VIEW ON THE PROBLEM (LITERATURE REVIEW)

Maintaining women's health and studying gender-related diseases remain priorities in medicine. The article is devoted to the actual problem of the present - hyperplastic processes of endometrium. In the problem of solving this pathology in recent years, a lot of information about etiology, causes of origin, diagnosis and treatment has been accumulated. The purpose of our search - a review of literature devoted to the factors of development, etiology and pathogenesis, which play the most important role in the development of hyperplastic processes of endometrium. The endometrium is a hormone-sensitive tissue that has the ability not only to cyclically renew almost all of the cellular composition, but also to a definite response to all changes in the hormones, cytokines, adhesion molecules, growth factors, biogenic amines and other biologically active substances at the level of the whole organism. The article deals with the main parts of the etiopathogene of this pathology, namely: an estrogenic stimulant, which is combined with progesterone deficiency, hormone-independent proliferation, inflammation, decreased apoptosis, pathological neoanogiogenesis, and also violations of the immune status in the endometrium. In addition, brief information is provided on new 
key elements of developmental factors, which contributes to a significant improvement in the problem resolution in the selection of pathogenetically valid diagnostic and treatment methods. The article shows that a normal cell growth process requires a delicate balance between hormones, growth factors and adhesion molecules, including integrin and apoptotic-linked genes. Revised literature sources point to a large number of cases of recurrent hyperplasia of the endometrium, which leads to increased control in the direction of onkocystrogenism. The new classification of endometrial hyperplasia (WH094) is proposed by the World Health Organization, which greatly simplifies the terminology and understanding of the problem for the clinician.

Key words: endometrial hyperplasia; oncological risk; apoptosis; steroid hormones.

Актуальність дослідження гіперпластичних процесів ендометрія зумовлена насамперед високим ризиком злоякісної трансорормації, проблемами, пов'язаними 3 порушеннями менструального циклу (МЦ), аномальними матковими кровотечами й анемією в жінок, а також із настанням і виношуванням вагітності в жінок репродуктивного віку. Це зумовлено високою частотою цієї патології в жінок репродуктивного та пременопаузального віку, недостатньою ефективністю лікування, значним відсотком інвалідизації жінок, ризиком малігнізації, що і $є$ однією 3 найбільш частих причин їх госпіталізації в гінекологічний стаціонар (від 10 до 18 \%) [2, 6].

За даними літератури, у структурі гінекологічних захворювань на частку гіперпластичних процесів ендометрія (ГПЕ) припадає від 15 до $50 \%$ [17, 19, 20]. В останні роки відзначено зростання патології ендометрія в жінок усіх вікових груп $[10,18]$, що пов'язують із несприятливою екологічною обстановкою та зниженням імунітету в жінок. Крім того, факторами ризику ГПЕ є: вік старше 35 років, відсутність вагітностей, пізня менопауза, раннє менархе, захворювання печінки і жовчного міхура, автоімунні процеси, ожиріння, куріння, сімейний анамнез раку ендометрія, яєчників, товстого кишечника, ожиріння і діабет II типу [4].

Частота злоякісного перетворення гіперпластичних процесів ендометрія коливається у межах 20-30 \% і визначається морфологічними та імуногістохімічними особливостями захворювання, його тривалістю, характером перебігу (частота рецидивів), а також віком та супутньою соматичною патологією пацієнток [4].

Серед пацієнток репродуктивного віку з безпліддям гіперпластичні процеси ендометрія виявляють 3 частотою до 50 \% випадків, і вони призводять до порушень репродуктивної функції. При цьому настання вагітності після лікування реалізується лише у 27 \% випадків [22].

Протягом кількох останніх десятиліть було запропоновано та використано багато різних систем класифікації гіперплазії ендометрія. Плутанина в термінології й розбіжності в критеріях між експертами, навіть у межах однієї й тієї самої країни, стали настільки серйозними, що в 1994 р. Всесвітня організація охорони здоров'я запропонувала свою класифрікацію гіперплазії ендометрія (WHO94). WHO94 використовує два критерії: наповненість ендометрія залозами (залозиста комплексність) і наявність ядерної атипії. Це дозволило виділити такі чотири категорії гіперплазії ендометрія, як: проста, комплексна, проста атипова й комплексна атипова гіперплазія, які мають різний ступінь ризику розвитку раку ендометрія -<1, 3, 8 і 29 \% відповідно; що значно спростить термінологію і розуміння проблеми для клініциста.

Ендометрій являє собою гормоночутливу тканину, яка має здатність не тільки до циклічного оновлення майже всього клітинного складу, а й до певного реагування на всі зміни гормонів, цитокінів, молекул адгезії, фракторів росту, біогенних амінів та інших біологічно активних речовин на рівні цілого організму. Ця взаємодія забезпечується завдяки комплексній мережі міжклітинних і внутрішньоклітинних сигнальних шляхів, у якій усі вищеперераховані молекули діють паракринно, автокринно або ендокринно.

Останніми роками велике значення надається процесам апоптозу, який відіграє провідну роль у функціонуванні жіночої репродуктивної системи [12]; bc1-2 є провідним геном, який визначає механізм клітинної загибелі, пригнічуючи апоптоз [14]. Упродовж менструального циклу (МЦ) загибель клітин ендометрія шляхом апоптозу та їх регенерація відбуваються в суворо регульованій послідовності й залежать від стадії циклу. Існує думка, що порушення процесів апоптозу мають фрундаментальне значення при гіперпролісреративних процесах і раковому переродженні клітин. Виявлення маркерів порушення процесу запрограмованої загибелі клітин на етапі ГЕ може дозволити своєчасно прогнозувати несприятливий перебіг хвороби й обирати оптимальну індивідуальну тактику лікування, спрямовану на збереження й відновлення генеративної фрункції в жінок репродуктивного віку та запобігання малігнізації [11].

Гіперплазія й атрофрія ендометрія можуть послідовно змінювати одна одну залежно від змін гормональних взаємовідносин у репродуктивній системі. Вважається, що активні у проліферативному відношенні естрогени - основний фрактор, що викликає гіперпроліферацію ендометрія, яка за відсутності впливу прогестерону прогресує в просту або комплексну гіперплазію ендометрія. Підвищені рівні фолікулостимулювального і лютеїнізувального гормонів мають стимулювальну дію на фрункцію яєчників, які відповідають підвищеною продукцією естрогенів, не компенсованих дією прогестерону. Ризик розвитку гіперпластичних захворювань ендо- і міометрія суттєво зростає на фоні порушень рецепторного і проліферативного стану ендометрія, роль яких у стимуляції клітинної проліферації остаточно не визначена. Не виключено, що в розвитку гіперпластичних і пухлинних захворювань важливу роль відіграє не тільки посилення процесів клітинної проліферації, але й порушення механізмів запрограмованої клітинної загибелі, що супроводжується накопиченням дефектних або клітин із надлишковою проліферацією та порушеною експресією рецепторів стероїдних гормонів - естрогенів і прогестерону [11], збільшення частоти цитогенетичних аномалій в ендометрії, міомі матки, що корелюють 3 такими у лімфоцитах перифреричної крові $[6,11]$. Наслідком цього нерідко $є$ поєднання гіперплазії ендометрія з лейоміомою матки, ендометріозом, доброякісними гормонально залежними захворюваннями молочних залоз. Однак, як свідчать інші дані, ці самі патологічні процеси виникають і без гіперестрогенемії. 
Було встановлено нові загальнобіологічні закономірності дії естрогенів і стероїдних гормонів загалом. Згідно з даними літератури, провідне значення в етіопатогенез ГПЕ відводиться надлишковій естрогенній стимуляції, що поєднується з недостатністю прогестерону $[13,19]$, гормон-незалежній проліфрерації [3, 17], запаленню [17], зниженому апоптозу $[15,16]$, патологічному неоангіогенезу [23], а також порушенням імунного статусу в ендометрії $[9,17]$. Ключовими ланками реалізації каскаду даних механізмів є процеси взаємодії широкого спектра цитокінів: фрактора некрозу пухлини, хемокінів, інтерореронів, фракторів росту та ін. [1, 21]. Ці цитокіни, володіючи рядом медико-біологічних ефектів (таких, як регуляція імунної відповіді, участь у запальних реакціях, контроль апоптозу, проліфрерація і ангіогенез), можуть бути залучені в етіопатогенез ГПЕ $[2,3]$.

У літературних джерелах $[8,20]$ відзначається велике число випадків рецидивування простої ГЕ (0,25-64,7 \%) (особливо в осіб із порушенням функції яєчників і запальними захворюваннями придатків матки), наявність якого, зважаючи на онконастороженість, часто стає вирішальною у виборі гістеректомії у жінок репродуктивного віку.

Проте в роботі І. О. Макарова і співавт. (2010) показано, що більш ніж у половині випадків за низького рівня рецепторів стероїдних гормонів у тканині ендометрія або навіть за їх відсутності спостерігається повне клінічне та морфрологічне одужання. У літературі з'являється дедалі більше повідомлень про те, що зміна концентрації статевих гормонів не є обов'язковою умовою для виникнення гіперпластичних процесів ендометрія. Автори $[15,23]$ говорять про невідповідність у рівні біодоступного Е2 при простій та складній ГЕ, що можна вважати основою для утвердження ролі цього чинника як головного у фрормуванні вираженості гіперплазій, оскільки вміст вільних естрогенів визначається не тільки рівнем загального E2 в плазмі крові, але і рівнем глобулінзв'язувальних статевих гормонів (ГЗСГ), що регулюється багатьма фракторами.

T. T. Nieminen et al. [21], R. J. Zaino et al. [22] відзначають, що при нормальній масі тіла естрогени стимулюють вироблення ГЗСг печінкою, однак при гіперінсулінемії, інсулінорезистентності, ожирінні, тобто при наявност метаболічних порушень, вміст у крові ГЗСГ знижується.

Науковими дослідженнями, виконаними в останнє десятиліття, доведено залежність метаболічних процесів від вмісту в організмі стероїдних гормонів. У той же час, як указувалось вище, самі стероїди мають можливість метаболізуватись у різних тканинах організму. Взаємодія інсулінозалежних тканин організму (жирової, м'язової, печінкової) і стероїдних гормонів представляє великий науково-практичний інтерес [14].

С. О. Дубовина та співавт. [5] у своїх дослідженнях довели прямий стимулювальний вплив на ендометрій інсуліну й інсуліноподібного чинника зростання [21], кількість і біодоступність якого при гіперінсулінемії збільшені [22]. G. L. Mutter et al. [23] повідомляють, що гіперандрогенія посилює стимулювальну дію епідермального фрактора росту на проліферацію ендометрія.

Вважається, що в більшості випадків внутрішньоматкова гіперплазія з атипією і гіперплазія ендометрія без атипії беруть початок з єдиної клітини-попередника, можливо, в результаті генетичних альтерацій.
Виявлено залежність між активністю металопротеїназ і апоптозом ендометрія: набуття окремими клітинами ендометрія проліферативної автономії (як ланка патогенезу) шляхом порушення сигнальної трансдукції, в тому числі металопротеїназ, зокрема MMP-9 і CD1, і пригнічення процесів апоптозу в цілому [7, 15]. Виявлено залежність між активністю металопротеїназ і апоптозом ендометрія.

Нормальний процес росту клітин вимагає тонкого балансу між гормонами, фракторами росту та молекулами адгезії, у тому числі інтегринами й апоптоз-зв'язаними генами; зміна синтезу та/або експресії цих фракторів може зумовлювати розвиток доброякісних або злоякісних проліфреративних захворювань. Серед перерахованих фракторів інтегрини, які належать до великого суперсімейства рецепторів клітинної адгезії, координують розпізнавання клітинно-позаклітинного матриксу й піддаються динамічним змінам у межах МЦ в жіночому ендометрії, крім того, вони є молекулами адгезії при імплантації ембріона.

Автори описують порушення тканинного ремоделювання і гістологічної диференціації клітин ендометрія 3 виникненням злоякісних процесів неоплазми під впливом дисметаболізації матриксних металопротеїназ [8, 11].

Водночас інтегрини відіграють найважливішу роль у репродукції, в рецептивності ендометрія. Спільна продукція $\beta 3-$, $\beta 4-$ і $\alpha 1$-інтегринів спостерігається в залозистому епітелії тільки в період вікна імплантації. У жінок із різними видами безпліддя виявляють порушення секреції avß3-інтегринів.

Численні дослідження останніх років присвячено оцінці експресії в ендометрії в нормі та патології фракторів росту і їх рецепторів, а також фракторів проліферації (ядерного антигена проліферувальних клітин (PCNA, Ki-67), необхідних для реплікації геномної ДНК. Так, в одних дослідженнях виявлено збільшення експресії маркерів проліфрерації в гіперплазованому ендометрії [7, 8], в той час як в інших отримані дані про низьку експресію Кi-67 та PCNA [11] і відсутність істотних відмінностей в їх експресії при різних формах ГЕ.

В останні роки встановлено, що в регуляції процесів клітинної проліферації ендометрія беруть участь не тільки естрогени, а й біологічні аміни (норадреналін, мелатонін, серотонін, гістамін, інсулін, простагландини), хоріогонін та інші пептиди, які продукуються клітинами так званої дисузної ендокринної системи - Amine Precursor Uptake and Decarboxylation (APUD-системи) [8]. У нормі апудоцити наявні в багатьох органах, проте в злоякісних нейроендокринних пухлинах різної локалізації, у тому числі в ендометрії, виявляється багаторазове підвищення їх концентрації [11].

При аналізі молекулярних основ розвитку ГЕ велика увага приділяється стану екстрацелюлярного матриксу, а також фрерментам, які беруть участь у його модифрікації. В цьому зв'язку І. Макаров, Т. Овсяннікова та співавт. [9] метою дослідження поставили визначення ролі лізилоксидази (LOX) в генезі ГЕ. Основною її фрункцією $€$ ініціювання обертання міжмолекулярних крос-зшивок у колагені й еластині, що сприяє підвищенню міцності та пружності волокон, а також фрормуванню цілісної структури цих волокон. Отже, для нормальної життєдіяльності організму необхідна LOX. У ході досліджень доведено, що LOX бере участь у контролі за внутрішньоклітинною 
активністю, експресія LOX значимо збільшується при гіпоксії, при цьому встановлено зв'язок між експресією LOX і фрактора, що індукує гіпоксію (HIF).

Одним із ключових фракторів успішного настання вагітності $€$ стан ендометрія в період вікна імплантації. Саме в цей період активуються процеси апоптозу в ендометрії і їх наявність виступає в ролі біологічного маркера адекватно підготовленого до імплантації ендометрія.

Відомо, що ендокринна та імунна системи жіночого організму тісно взаємопов'язані [8]. В нормальному ендометрії залежно від фрази МЦ змінюється субпопуляційний склад лейкоцитів. У середній стадії секреторної фрази в ендометрії переважають натуральні кілерні (НК) клітини, що експресують CD56+ і CD16-, які розглядаються як ланка місцевих імунних механізмів, що беруть участь в імплантації і розвитку вагітності.

Висновок. На сучасному етапі, незважаючи на вдосконалення діагностичних, терапевтичних і хірургічних методів, проблема лікування гіперпластичних процесів ендометрія залишається актуальною. Складність і неоднорідність патогенезу захворювання, різноманітність тлумачень окремих його ланок, неоднозначність тактичних підходів (з/без урахування індивідуальних особливостей гормональних порушень) створюють певні труднощі у виборі патогенетично обґрунтованого лікування, особливо гормональної терапії. Саме цими обставинами зумовлений підвищений науковий і практичний інтерес до цієї проблеми.

\section{СПИСОК ЛІТЕРАТУРИ}

1. Полиморфизм ферментов метаболизма эстрогенов у женщин с гиперпластическими процессами в эндометрии в период перименопаузы / Н. В. Артымук, Е. Л. Харенкова, Е. В. Иленко, Л. Ф. Гуляева // Российский вестник акушерагинеколога. - 2009. - Т. 9, № 2. - С. 17-20.

2. Бенюк В. О. Сучасні підходи до діагностики гіперпластичних процесів ендометрія у жінок репродуктивного віку / В. О. Бенюк, В. В. Курочка, В.М.Гончаренко // Проблемы, достижения и перспективы развития медико-биологических наук и практического здравоохранения. - 2009. - Т. 145, № 3. - C. 3004-3005.

3. Веропотвелян П. М. Поліморфізм фрерментів метаболізму естрогенів у пацієнток з гіперплазією в ендометрії в пізньому репродуктивному віці / П. М. Веропотвелян, М. П. Веропотвелян, С. П. Яручик // ПАГ. - 2012. - № 5. - С. 73

4. Вовк И. Б. Современные представления о гиперплазии эндометрия / И. Б. Вовк, О. Ю. Борисюк, Н. Е. Горбань // Медична газета «Здоров'я України». Гінекологія. Акушерство. Репродуктологія. - 2016. - № 2 (22). - С. 70-73.

5. Патогенетические аспекты гиперпластических процессов в эндометрии у женщин с метаболическим синдромом / С. О. Дубовина, Н. Н. Скачков, Ю. Д. Берлим [и др.] // Российский вестник акушера-гинеколога. - 2008. - № 3. - С. 41-44.

6. Запорожан В. Н. Современная диагностика и лечение гиперпластических процессов эндометрия / В. Н. Запорожан, Т. Ф. Татарчук, В. Г. Дубинина // Репродуктивная эндокринология. - 2012. - № 1 (3). - С. 5-12.

7. Клинышкова Т. В. Клинико-морфологическое обоснование оптимизации лечения больных с гиперплазией эндометрия / Т. В. Клинышкова, Н. Б. Фролова, С. И. Мозговой // Российский вестник акушера-гинеколога. - 2010. № 34. - С. 16-20.

8. Лысенко О. В. Гиперпластические процессы эндометрия в различные возрастные периоды: исследование цитокинового статуса и содержания SFAS-лиганда / О.В.Лысенко, С. Н. Занько // Акушерство и гинекология. 2011. - № 4. - С. 63-68.

9. Макаров И. О. Молекулярные аспекты гиперпластических процессов в эндометрии / И. О. Макаров, Т. В. Овсянникова, Н. А. Шешукова // Российский вестник акушера-гинеколога. - 2010. - Т. 10, № 6. - С. 18-21.

10. Комплексное лечение гиперпластических процессов эндометрия у больных периода пре- и постменопаузы / К. А. Мартиросян, И. В. Караченцова, А. П. Политова [и др.] // Вестник РГМУ. - 2011. - Спец. вып. № 2. - С. 109-112. (Современные вопросы акушерства, гинекологии и перина- тологии : материалы V Междунар. конср. молодых ученых, Москва, 20 мая 2011 г.).

11. Рожковська Н. М. Диференційовані підходи до органозберігаючого лікування гіперпластичних процесів ендометрія / Н. М. Рожковська, Д. М. Железов, В. О. Ситнікова // Здоровье женщины. - 2009. - № 7. - С. 98-101.

12. Сидорова И. С. Современный взгляд на проблему гиперпластических процессов в эндометрии / И. С. Сидорова, Н.А.Шешукова, А. С. Федотова // Российский вестник акушера-гинеколога. - 2008. - Т. 8, № 5. - С. 18-22.

13. Татарчук Т. Ф. Гиперпластические процессы эндометрия: что нового? / Т. Ф. Татарчук, Л. В. Калугина, Т. Н. Тутченко // Репродуктивная эндокринология. - 2015. - № 5 (25). - С. 7-13.

14. Чайка В. К. Диффреренцированный подход к комплексному лечению гиперпластических процессов эндометрия у женщин репродуктивного возраста / В. К. Чайка, Ю. А. Малова, И. Г. Постолюк // Здоровье женщины. - 2007. - № 3 (31). - С. 79-83.

15. Экспрессия генов, регулирующих апоптоз, при разных типах гиперплазии эндометрия и эндометриоидной карциноме / Г. Е. Чернуха, М. Р. Думановская, О. В. Бурменская [и др.] // Акушерство и гинекология. - 2013. - № 1. - С. 63-69.

16. Чернуха Г. Е. Экспрессия рецепторов к половым стероидным гормонам и клеточная пролиферация при разных формах гиперплазии эндометрия. Влияние внутриматочной левоноргестрел-рилизинг-системы / Г. Е. Чернуха, Т. В. Шигорева, О. А. Могиревская // Акушерство и гинекология. - 2011. - № 6. - С. 64-69.

17. Шешукова Н. А. Гиперпластические процессы эндометрия: особенности пролиферативной активности при сочетании с хроническим эндометритом / Н. А. Шешукова, И. О. Макаров, Т.В.Овсянникова // Акушерство, гинекология и репродукция. - 2011. - Т. 5, № 3. - С. 10-15.

18. Acmaz G. Evaluation of endometrial precancerous lesions in postmenopausal obese women-a high risk group? / G. Acmaz, H. Aksoy, E. Albayrak [et al.] // Asian. Pac. J. Cancer Prev. - 2014. - Vol. 15, No. 1. - P. 195-198.

19. Stage I noninvasive and minimally invasive uterine serous carcinoma: comprehensive staging associated with improved survival / R. L. Giuntoli, M. A. Gerardi, A.V. Yemelyanova [et al.] // Int. J. Gynecol. Cancer. - 2012. - Vol. 22, No. 2. - P. 273-279.

20. Absolute risk of endometrial carcinoma during 20year follow-up among women with endometrial hyperplasia / J. V. Lacey, M. E. Sherman, B. B. Rush [et al.] // J. Clin. Oncol. - 2010. - Vol. 28, No. 5. - P. 788-792. 
21. Nieminen T.T. Molecular analysis of endometrial tumorigenesis: importance of complex hyperplasia regardless of atypia / T. T. Nieminen, A. Gylling, W. M. Abdel-Rahman // Clin. Cancer Res. - 2009. - Vol. 15 (18). - P. 5772-5783.
22. Zaino R. J. Reproducibility of the diagnosis of atypical endometrial hyperplasia / R. J. Zaino, J. Kanderer, C. L. Trimble // Cancer. - 2006. - Vol. 106. - P. 804-811.

23. Benign endometrial hyperplasia sequence and endometrial intraepithelial neoplasia / G. L. Mutter, R. J. Zaino, J. P. A. Baak [et al.] // Int. J. of Gyn. Pathol. - 2007. - Vol. 26, No. 2. - P. 103-114.

\section{REFERENCES}

1. Artymuk, N.V., Kharenkova, E.L, Ilenko, E.V., \& Gulyaeva, L.F. (2009). Polimorfizm fermentov metabolizma estrogenov u zhenshchin z giperplasticheskimi protsessami [Polymorphism of estrogen metabolism enzymes in women with hyperplastic processes in the endometrium during perimenopause]. Rossiyskiy vestnik akushera-ginekologa - Russian Bulletin of ObstetricianGynecologist, 9 (2), 17-20 [in Russian].

2. Beniuk, V.O., Kurochka, V.V., \& Honcharenko, V.M. (2009). Suchasni pidkhody do diahnostyky hiperplastychnykh protsesiv endometriia u zhinok reproduktyvnoho viku [Modern approaches to the diagnosis of hyperplastic processes of endometrium in women of reproductive age]. Proplemy, dostizheniya i perspektivy razvitiya mediko-biologicheskikh nauk i prakticheskogo zdravookhraneniya - Problems, Achievements and Prospects of Development of Medical-biological Sciences and Practical Health Care, 145 (3), 3004-3005 [in Ukrainian].

3. Veropotvelian, P.N, Verppotvlian, M.P, \& Yaruchyk, S.P (2012). Polimorfizm fermentiv metabolizmu estroheniv u patsiientok $z$ hiperplaziieiu $v$ endometrii v piznomu reproduktyvnomu vitsi [Polymorphism of enzymes metabolism of estrogens in patients with hyperplasia in the late reproductive age of endometrium]. $P A H, 5,73$ [in Ukrainian].

4. Vovk, I.B., Borisyuk, O.Yu., \& Gorban, N.E. (2016). Sovremennye predstavleniya o giperplazii endometriya [Contemporary notions about endometrial hyperplasia]. Medychna hazeta "Zdorovia Ukrainy." Hinekolohiia. Akusherstvo. Reproduktolohiia - Medical newspaper "Health of Ukraine" Gynecology. Obstetrics. Reproductology, 2 (22), 70-73 [in Ukrainian].

5. Dubovina, S.O, Skachkov, N.N, \& Berlim, Yu.D. (2008). Patogeneticheskiye aspekty giperplasticheskikh protsessov $v$ endometrii $u$ zhenshchin $s$ metabolicheskim sindromom [Pathogenesis - aspects of hyperplastic processes in endometrium in women with metabolic syndrome]. Rossiyskiy vestnik akushera-ginnekologa - Russian Messenger of ObstetricianGynecologist, 3, 41-44 [in Russian].

6. Zaporozhan, V.N., Tatarchuk, V.G., \& Dubinina, N.V. (2012). Sovremennaya diagnostika i lecheniye giperplasticheskikh protsessov endometriya [Modern diagnostics and treatment of hyperplastic processes of endometrium]. Reproduktivnaya endokrinologiya - Reproductive Endocrinology, 1 (3). 5-12 [in Russian].

7. Klinyshkova, T.V., Frolova, N.B., \& Mozgovoy, S.I. (2010). Kliniko-morfologicheskoye obosnovaniye optimizatsii lecheniya bolnykh s giperplaziyey endometriya [Clinical-Morphological substantiation of optimization of treatment of patients gyperplasia of the endometrium]. Rossiyskiy vestnik akushera-ginekologa - Russian Messenger of Obstetrician-Gynecologist, 34, 16-20 [in Russian].

8. Lysenko, O.V., \& Zanko, S.N. (2011). Giperplasticheskiye protsessy endometriya $v$ razlichniye vozrastnye periody: issledovaniye tsytokinovogo statusa i soderzhaniya SFAS-liganda [Hyperplastic processes of enpre-metritis idifferent age groups: cytokinethe new status and content of the SFAS-ligand]. Aku- sherstvo i ginekologiya - Obstetrics and Gynecology, 4, 63-68 [in Russian].

9. Makarov, I.O., Ovsyannikova, T.V., \& Sheshukova, N.A. (2010). Molekulyarnye aspekty giperplasticheskikh aspektov $v$ endometrii [Molecular aspects of hyperplastic processes in the endometrium]. Rossiyskiy vestnik akushera-ginekologa Russian Bulletin of Obstetrician-Gynecologist, 10 (6), 18-21 [in Russian].

10. Martirosyan, K.A., Karachentsova, I.V., \& Politova, A.P. (2011). Kompleknoye lecheniye giperplasticheskikh protsessov endometriya u bolnykh perioda pre- i postmenopauzy [Complex treatment of endometrial hyperplastic processes in patients of the pre- and postmenopausal period]. Vestnik RGMU - Bulletin of RSMU, 2, 109-112 [in Russian].

11. Rozhkovska, N.M., Zhelezov, D.M. \& Sytnikova, V.O. (2009). Dyferentsiiovani pidkhody do orhanozberihaiuchoho likuvannia hiperplastychnykh protsesiv endometriia [Differentiated approaches to organo-preserving treatment of endometrial hyperplastic processes]. Zdorovye zhenshchiny - Health of Woman, 7, 98-101 [in Ukrainian].

12. Sidorova, I.S., Sheshukova, N.A., \& Fedotova, A.S. (2008). Sovremennyy vzglyad na problemy giperplasticheskikh protsessov $v$ endometrii [Contemporary a look at the problem of hyperplastic processes in the endometrium]. Rossiyskiy vestnik akushera-ginekologa - Russian Bulletin of ObstetricianGynecologist, 8 (5), 18-22 [in Russian].

13. Tatarchuk, T.F., Kalugina, Yu.A., \& Tutchenko, T.N. (2015). Giperplasticheskiye protsessy endometriya: chto novogo? [Hyperplastic processes of endometrium: what's new?]. Reproduktivnaya endokrinologia - Reproductive Endocrinology, 5 (25), 7-13 [in Russian].

14. Chayka, V.K., Malova, I.G., \& Postolyuk, L.V. (2007). Differentsirovanyy podkhod k kompleksnomu lechenniyu giperplasticheskikh protsessov endometriya u zhenshchin reproduktivnogo vozrasta [Differentiated approach to complex treatment of endometrial hyperplastic processes in women of reproductive age]. Zdorovye zhenshchiny - Health of Women, 3 (31), 79-83.

15. Chernukha, G.E., Dumanovskaya, M.R., \& Burmenskaya, O.V. (2013). Ekspressiya genov, reguliruyushchikh apoptoz, pri raznykh tipakh giperplazii endometriya i endometrioidnoy kartsynome [Expression of genes regulating apoptosis, with different types of hyperplasia endometrial and endometrioid carcinoma syndrome]. Akusherstvo i ginekologiya - Obstetrics and Gynecology, 1, 63-69.

16. Chernukha, G.E, Shigoreva, T.V., \& Mogirevskaya, O.A. (2011). Ekspressiya retseptorov k polovym steroidnym gormonam i kletochnaya proliferatsiya pri raznykh formakh giperplazii endometriya. Vliyaniye vnutrimatochnoy levonorgestrel-rilizingsistemy [Expression of receptors for sex steroid hormones and cell proligation in different forms of endometrial hyperplasia. Influence intrauterine device levonorgestrel-leasing system]. Akusherstvo i ginekologia - Obstetrics and Gynecology, 6, 6469 [in Russian]. 
17. Sheshukova, N.A., Makarov, I.O., \& Ovsyannikova, T.V. (2011). Giperplasticheskiye protsessy endometriya: osobennosti proliferativnoy aktivnosti pri sochetanii s khronicheskim endometritiom [Hyperplastic endometrial processes: features of proliferative activity when combined with chronic endometritis]. Akusherstvo, ginekologiya i reproduktsiya - Obstetrics, Gynecology and Reproduction, 5 (3), 10-15 [in Russian].

18. Acmaz, G., Aksoy, H., \& Albayrak, E. (2014). Evaluation of endometrial precancerous lesions in postmenopausal obese women-a high risk group? Asian. Pac. J. Cancer Prev., 15 (1) 195-198.

19. Giuntoli, R.L., Gerardi, M.A., \& Yemelyanova, A.V. (2012) Stage i noninvasive and minimally invasive uterine serous carcinoma: comprehensive staging associated with improved survival. Int. J. Gynecol. Cancer, 22 (2), 273-279.
20. Lacey, J.V., Sherman, M.E., \& Rush, B.B. (2010). Absolute risk of endometrial carcinoma during 20-year follow-up among women with endometrial hyperplasia, J. Clin. Oncol., 28 (5), 788-792.

21. Nieminen, T.T., Gylling, A., \& Abdel-Rahman, W.M. (2009). Molecular analysis of endometrial tumorigenesis: importance of complex hyperplasia regardless of atypia. Clin. Cancer Res., 15 (18), 5772-5783.

22. Zaino, R.J., Kanderer, J., \& Trimble, C.L. (2006). Reproducibility of the diagnosis of atypical endometrial hyperplasia. Cancer, 106, 804-811.

23. Mutter, G.L., Zaino, R.J., \& Baak, J.P.A. (2007). Benign endometrial hyperplasia sequence and endometrial intraepithelial neoplasia. Int. J. of Gyn. Pathol., 26 (2), 103-114.

Отримано 12.02 .19 